GLOBAL JOURNAL OF AGRICULTURAL SCIENCES VOL. 18, 2019: 73-85

COPYRIGHT@ BACHUDO SCIENCE CO. LTD PRINTED IN NIGERIA ISSN 1596-2903 www.globaljournalseries.com, Email: info@globaljournalseries.com

\title{
THE EFFECT OF MICROCREDIT ON TECHNICAL EFFICIENCY OF SMALLHOLDER RICE FARMERS IN IKOT EKPENE AGRICULTURAL ZONE, AKWA IBOM STATE, NIGERIA.
}

\author{
EDET, O. G., AGBACHOM E. E. AND UWAH, E. D.
}

(Received 17 June 2019; Revision Accepted 24 July 2019)

\begin{abstract}
The study analyzed the effect of microcredit on technical efficiency of smallholder rice farmers in Akwa Ibom State, Nigeria. The specific objectives were to; describe the socio-economic profile of the rice farmers in the study area; identify microcredit sources accessed by rice farmers; analysis the factors that determine access to credit as well as examine the influence of credit and other factors on technical efficiency. A multi-stage sampling technique was employed to sample the rice farmers in the study area. Data obtained was analyzed using descriptive statistics, profit regression and stochastic production frontier. Results showed that $64.7 \%$ were male, $68.2 \%$ were married, and about $96.5 \%$ were literate. The mean household size was 7 persons per households, with a mean farm size of 2.19 hectares, $38.8 \%$ had 6 -10years of farming experience, and $83.5 \%$ belonged to an association and earned an annual income of above $\$ 400,000$. The main source of credit accessed by the smallholder rice farmers is the cooperative society. Extension contact, farm size, farming experience and household size were the significant factors that determined the access to credit by the smallholder farmers. Quantity of seed, farm size and family labour were the significant variables that had a significant effect on the output of rice at $1 \%$ and $5 \%$. The value of the returns to scale (RTS $=0.914$ ) shows that the farmers were producing at the decreasing return to scale (Stage II). The mean technical efficiency was 0.64 with minimum and maximum efficiencies of 0.09 and 0.92 . Respondent's educational level, household size, farming experience and credit were the significant variables that increased the technical efficiency of the smallholder rice farmers. The study recommends that smallholder rice farmer should increase access to credit per production season, since the access to credit has efficiency increasing effect
\end{abstract}

KEYWORDS: Microcredit, Technical Efficiency, Smallholder Rice Farmers

\section{INTRODUCTION}

Rice is from the family Gramineae, Genus oryza, and species; sativa, glaberrina, longistaminata and nivara. It was taken into West Africa in early $19^{\text {th }}$ century (Jirgi, Abdurrahman and Ibrahim, 2009). It is the leading cereal crop which can be grown in the standing water areas of flat, low lying tropical soils according to West Africa Rice Development Association (2003). Akunde (2002) optioned that rice is a staple food for most people than any other crop and $90 \%$ of it is grown and consumed in South East
Asia which is a major center of the world population. It is an increasingly important crop in Nigeria, thus, it is grown for sale and home consumption. Rice is known as one of the major cereals and has assumed cash crop status in Nigeria, especially in the production areas, where it produces employment and income for more than $80 \%$ of the rural farmers as a result of the activities that take place along the production and distribution chains from cultivation and consumption (Imolelin and Wada 2002).

Edet, O. G., Department of Agricultural Economics, University of Calabar, Calabar. Cross River State, Nigeria.

Agbachom E. E., Department of Agricultural Economics, University of Calabar, Calabar. Cross River State, Nigeria. Uwah, E. D., Department of Agricultural Economics, University of Calabar, Calabar. Cross River State, Nigeria. 
Moreover, rice production, its consumption or demand is growing faster than any other major staples.

However, rice production system is beset with problems associated with poor access to credit/capital base, low-labour output, low yield, and relatively high production costs of labour, poor acquisition of land, poor producer price and marketing system. In line with this, Adeniyi (1987) observed that related problems of that nature have led to the low yield and hence the decline in the local production of this crop by rural farmers. Though it is a major staple food in Nigeria, its domestic production has never been able to meet demand (FAO, 2015). It is on this note that Rahji and Fakayode (2009) observed that the demand and supply gap in rice production is widening, resulting in huge import bill on rice.

One of the major factors responsible for low agricultural productivity in Nigeria is farmers' limited access to production inputs and credits which are necessary for attaining a high level of production (Nwaru, 2004). Amaza and Olayemi (2002) observed that crop farmers mostly carry out their production under conditions involving the use of inefficient tools and unimproved seed varieties and therefore, maximum efficiency is elusive to them. Production credit is essential in enhancing the technical efficiency and welfare of smallholder farmers in Africa. Credit affects farm production directly and indirectly (Brambilla and Potor, 2005, and Guirkinger and Bourcher, 2005). However, smallholder farmers face the challenge to access credit.

Rice is extensively cultivated in Akwa Ibom State but there is little information on the effect of credit on the technical efficiency of smallholder's rice farmers. One way farmers can raise productivity is improving the efficiency within the limit of the existing resource base and technology (Udoh, 2005). Productivity is reduced in the presence of technical inefficiency whereas the more efficient the firm, the higher its productivity, ceteris paribus. Boosting rice production would require that farm resources be use efficiently since efficiency in the use of the production inputs is essential for optimum production. Numerous studies have been carried out on the technical efficiency of rice farmers in Nigeria (Oladeebo, 2007). However, limited studies exist in Ikot Ekpene Agricultural zone relating credit to technical efficiency of smallholder farmer. Hence, this necessitated the study which seeks to address the following questions.

i What are the socio-economic profiles of the respondents in the study area?

ii What area the different credit sources available to the respondents in the study area?

iii What are the factors that determine the access to credits by the respondents? iv What is the influence of credit and other factors on the technical efficiency of rice farmers in the study area?

\section{Study Objectives:}

The general objective of this study was to analyze the effect of credit on technical efficiency of smallholder rice farmers in Ikot Ekpene Agricultural Zone, Akwa Ibom State. The specific objectives were to:

i. describe the socio-economic profile of rice farmers in the study area.

ii. identify credit sources accessed by small holder rice farmers in the study area.

iii. analyze the factors that determine access to credit by the rice farmers.

iv. examine the influence of credit and other factors on technical efficiency of rice farmers in the study area.

\section{JUSTIFICATION OF THE STUDY}

Over the years, credit has emerged as an effective strategy for poverty alleviation which is a very important aspect of the Millennium Development Goals (MDGs) (Iganiga, 2008). Specifically, to the government and policy makers, it will serve as a yardstick for appraising the policy shifts of the government towards regulating farmers' access to credit. To the farmers, the study will provide useful information and technical advice to rice farmers on how to allocate limited resources efficiently in orders minimize cost. To the students/fellow researchers, it would serve as a reference material for further research.

\section{METHODOLOGY: Study Area:}

Akwa Ibom State is situated in the South-South geopolitical zones in Nigeria, and is bordered on the east by Cross River State, on the West by Rivers State and Abia State, and on the South by the Atlantic Ocean. Geographically, it lies between latitude $4^{\circ} 32^{\prime}$ and $5^{\circ} 33^{\prime} \mathrm{N}$, and longitude $7^{\circ} 35^{\prime}$ and $8^{\circ} 25^{\prime} \mathrm{E}$. it occupies a total area of $7,245,933 \mathrm{~km} 2$ (kilometers square) and estimated population of $5,482,200$ (National Population Commission, NPC, 2016). The state has six (6) Agricultural Development Programme (ADP) zones namely: Uyo, Ikot Ekpene, Oron, Abak, Eket and Etinan. The people are predominantly farmers producing such food crops as rice, palm oil, cassava, maize, melon, sweet potatoes, cocoyam, fluted pumpkin, pepper, among others.

\section{SAMPLING PROCEDURE}

A multistage sampling technique was employed in the study. The first stage was the purposive selection of four (4) blocks (Ukpomita, ibiaku Ntok Okpo, Ikpe Ikot Nkon and Aka Ekpeme) out of the eight (8) blocks in 
Ikot Ekpene Agricultural Zone on the basis of predominance of ADP registered rice farmers. In stage two, fifty percent $(50 \%)$ of the cells in each of the selected blocks in (in stage one) was randomly selected to have a total of 17 cells. In stage three, five (5) rice farmers from each of the 17 sampled cells were selected, to achieve a proportionate and even spread in the study area thus giving a total sample sizes of eight five (85) respondents for the study.

\section{DATA ANALYSIS}

\section{MODEL SPECIFICATION}

\section{Logit Regression model}

The logit regression model was estimated as:

$Y=\beta_{0}+\beta_{1} X_{1}+\beta_{2} X_{2}+\beta_{3} X_{3}+\beta_{4} X_{4}+\beta_{5} X_{5}+\beta_{7} X_{7}+e$

Where;

$Y=$ Access to credit (1 if respondent has received credit and 0 if otherwise)

$X_{1}=$ Age of the respondents (in years)

$X_{2}=$ Sex of the respondents (male $=1$, female $=0$ )

$\mathrm{X}_{3}=$ Household size (number of persons)

$\mathrm{X}_{4}=$ Farm size (hectares)

$X_{5}=$ Marital status ( married $=1$, otherwise $=0$ )

$\mathrm{X}_{6}=$ Farming experience (in years)

$X_{7}=$ Years of formal education

$B_{1}-\beta_{7}=$ Parameters to be estimated

$\mathrm{B}_{0}=$ Intercept

$\mathrm{e}=$ error term

Stochastic frontier model

This methodology has been used by many researchers including Battere et al., (1996). The production technology of the former is specified by the Cob-Douglas frontier production function.

$\operatorname{LnY}=\beta_{0}+\beta_{1} \operatorname{LnX} X_{1}+\beta_{2} \operatorname{LnX} X_{2}+\beta_{3} \operatorname{LnX} X_{3}+\beta_{4} \operatorname{LnX} X_{4}+\beta_{5} \operatorname{LnX}{ }_{5}$ + vi-ui ... (2)

Where;

$\mathrm{Y}=$ Output (grain equivalent)
Objective 1: The socio-economic profile of the rice farmers was analyzed using percentages, frequencies, tables, means and standard deviation.

Objective 2: Identify credit sources accessed by small holder rice farmers were analyzed using percentages and frequency counts.

Objectives 3: Analyze the factors that determine access to credit by the respondents was analyzed using logit regression model.

Objective 4: Examine the influence of credit and other factors on technical efficiency were analyzed using stochastic frontier model.

$\mathrm{X}_{1}=$ Quantity of seed (kgs or tons)

$\mathrm{X}_{2}=$ Farm size (hectare)

$X_{3}=$ Quantity of fertilizer (kgs)

$\mathrm{X}_{4}=$ Hired labor (man day)

$\mathrm{X}_{5}=$ Family labour (man day)

$\mathrm{Vi}=$ Random variables which are assumed to be independent of Ui, identical and normally distributed with zero mean and constant variance i.e $\mathrm{N}\left(\mathrm{o}, \delta^{2}\right)$.

Ui=Non-negative random and variables which are assumed to account for technical inefficiency in production and are assumed to be independent of vi such that it is the non-negative truncated (ut zero) of half normal distribution (Coelli, 1995; Battase, and Carra, 1977).

The inefficiency effect model is specified thus:

$\mathrm{Ui}$ is modeled in terms of the socioeconomic factors that affect the technical efficiency of the farmers

$U i=\delta_{0}+\delta_{1} z_{1}+\delta_{2} z_{2}+\delta_{3} z_{3}+\delta_{4} z_{4}+\delta_{5} z_{5}+\delta_{6} z_{6}+\delta_{7} z_{7}+$ $\delta_{8} z_{8} \ldots \ldots \ldots \ldots \ldots \ldots \ldots . . .(3)$

Where;

$\mathrm{Z}_{1}=$ Age (year)

$Z_{2}=$ Marital status $(1=$ married, $0=$ otherwise $)$

$\mathrm{Z}_{3}$ =Educational level (years of schooling)

$Z_{4}=$ Household size (number of persons)

$Z_{5}=$ Farming experience (years)

$\mathrm{Z}_{6}=$ Extension contact (number of contact)

$Z_{7}=$ Access to credit (yes $=1$, no $=0$ ) 
RESULTS AND DISCUSSION:

Table 1: Socio-economic characteristics of rice farmers

\begin{tabular}{|c|c|c|}
\hline Variable & Frequency & Percentage \\
\hline \multicolumn{3}{|l|}{ Gender } \\
\hline Male & 55 & 64.7 \\
\hline Female & 30 & 35.3 \\
\hline Total & 85 & 100 \\
\hline \multicolumn{3}{|l|}{ Age } \\
\hline$\leq 30$ & 31 & 36.5 \\
\hline $31-40$ & 23 & 27.1 \\
\hline $41-50$ & 22 & 25.9 \\
\hline $51-60$ & 5 & 5.8 \\
\hline$>60$ & 4 & 4.7 \\
\hline Total & 85 & 100 \\
\hline Mean & 37.66 & \\
\hline \multicolumn{3}{|l|}{ Marital status } \\
\hline Single & 21 & 24.7 \\
\hline Married & 58 & 68.2 \\
\hline Divorced & 2 & 2.4 \\
\hline Widowed & 4 & 4.7 \\
\hline Total & 85 & 100 \\
\hline \multicolumn{3}{|l|}{ Educational level } \\
\hline No formal education & 3 & 3.5 \\
\hline Primary education & 7 & 8.2 \\
\hline Secondary education & 49 & 57.7 \\
\hline Tertiary education & 26 & 30.6 \\
\hline Total & 85 & 100 \\
\hline \multicolumn{3}{|l|}{ Household size } \\
\hline$<6$ & 31 & 36.5 \\
\hline $6-10$ & 48 & 56.5 \\
\hline $11-15$ & 5 & 5.9 \\
\hline $16-20$ & 1 & 1.1 \\
\hline$>20$ & - & - \\
\hline Total & 85 & 100 \\
\hline Mean & 6.95 & \\
\hline \multicolumn{3}{|l|}{ Farm size } \\
\hline$\leq 3$ & 67 & 78.8 \\
\hline $4-6$ & 17 & 20.0 \\
\hline $7-8$ & 1 & 1.2 \\
\hline Total & 85 & 100 \\
\hline Mean & 2.19 & \\
\hline \multicolumn{3}{|c|}{ Member to Association } \\
\hline Yes & 71 & 83.5 \\
\hline No & 14 & 16.5 \\
\hline Total & 85 & 100 \\
\hline
\end{tabular}




\section{Farming experience}

$<6$
$6-10$
$11-15$
$16-20$
$>20$
Total
Mean

\section{Extension contact}

$\begin{array}{ll}\text { Yes } & 42 \\ \text { No } & 43 \\ \text { Total } & 85\end{array}$

$\begin{array}{ll}10 & 11.8 \\ 33 & 38.8 \\ 22 & 25.9 \\ 14 & 16.4 \\ 6 & 7.1 \\ 85 & 100 \\ 12.34 & \end{array}$

\section{Number of visit}

$\leq 3$

4-6

7-8

Total

Mean

42

43
85

49.4

50.6

100

56.5

36.5

Engaged in other
business
Yes
No
Total

Annual income
$\leq 100,000$
$100,001-200,000$
$200,001-300,000$
$300,001-400,000$
$>400,000$
Total
Mean

7.0

100

$\begin{array}{ll}48 & 56.5 \\ 31 & 36.5 \\ 6 & 7.0 \\ 85 & 100\end{array}$

78.9

21.1

100

12.9

28.3

14.1

15.3

29.4

100

\section{Source: Field survey, 2018.}

Table 1 shows that $64.7 \%$ of the rice farmers were male while $35.3 \%$ were female. This indicated that majority of rice farmers are males also with $68.2 \%$ of them married and $24.7 \%$ being single. This implies that married individuals dominated among the sampled rice farmers. Rice farmers had a minimum age of 31 and maximum of 60 with an average age of 38. This implies that the rice farmers are in their active ages that could contribute and undertake rigorous activities of rice farming. Majority $(57.7 \%)$ of the respondents had secondary education, $30.6 \%$ had tertiary education while only $3.5 \%$ had no formal education. The results revealed that majority rice farmers were literate. The high literacy level in the area would enhance their involvement in rice production in the area. This finding agrees with that of Enwerem and Ohajianya (2013). They reported that $57.9 \%$ of small scale farmers spent $7-12$ years in formal education, thus implying that the rate of adoption of innovation is expected to be high in the area.

Majority $(56.5 \%)$ of the respondents had household size that ranged from $6-10$ persons and $5.9 \%$ of the respondent had family size of $16-20$ persons and a mean household size of 7 persons. The study showed that the respondents had large household size. The finding agrees with that of Erhabor and Ahmadu (2013). They reported that majority of the respondents were married with high average family size (10 persons).

Majority $(78.8 \%)$ of the rice farmers had farm sizes less than or equal to 3 ha and $1.2 \%$ had farm size within 7-8ha. The approximated average farm size is $2 \mathrm{ha}$. This implies that most of the farmers were not into small scale rice production due to the large farm size. $(83.5 \%)$ were member of an association, while $(16.5 \%)$ did not belong to any association. The high proportion of membership might enhance their access 
to agricultural information on improved techniques on rice production and easy access to credit to enhance their productivity. Majority $(38.8 \%)$ of the respondents had 6-10 years farming experience, $25.9 \%$ had $11-15$ years of farming experience, $16.4 \%$ had $16-20$ years of farming experience while only $7.1 \%$ of the respondent had above 20 years of farming experience. The average farming experience of the respondents is 12years. This implies that the respondents have been into rice production for a long time. However, it is expected that with increasing years of farming, respondents would gain experiences in farming to the advantage of increasing agricultural productivity. This agrees with the findings of Erhabor and Ahmadu (2013), they reported that the average farming experience of the respondents was high (17 years), the high level of experience may contribute to their ability to use resources more efficiently in their production.

Majority (50.6\%) did not have access to extension agent while $49.4 \%$ had access to extension agent.
However, majority (56.5\%) of the respondents were visited less than 4times a year while $36.5 \%$ were visited between 4-6times a year. The approximated average number of visit was 3times a year. The high proportion of respondents who did not have access to extension agent and the low number of visit may hamper their adoption of improved techniques of rice production which in turn have a serious implication on decreasing rice output.

Majority $(78.9 \%)$ of the respondents reported that they are into other business apart from rice production while $21.1 \%$ were strictly into rice production. this shows a strong diversification of enterprise in the area.

$29.4 \%$ of the respondents earned above $\$ 400,000$ annually, $28.3 \%$ earned within $100,001-200,000$, while $12.9 \%$ earned less than $\$ 100,001$. The average annual income was $318,764.71$. This income is from rice production only.

Table 2: Credit sources accessed by smallholder farmers

\begin{tabular}{lll}
\hline Variable & Frequency & Percentage \\
\hline Microfinance & 11 & 13 \\
Commercial Bank & 3 & 3.5 \\
Akwa lbom Agricultural loan scheme & 26 & 30.6 \\
Cooperative society & 45 & 52.9 \\
Total & $\mathbf{8 5}$ & $\mathbf{1 0 0}$ \\
\hline
\end{tabular}

\section{Source: field survey, 2018.}

Table 2 shows the main source of credit accessed by the smallholder rice farmers, the result revealed that the main source of credit accessed by the rice farmers is the cooperative society; about $52.9 \%$ of the rice farmers obtained their take off credit and fund for expansion from the cooperative society. This was followed by Akwa Ibom Agricultural Loan Scheme $(30.6 \%)$ and microfinance bank (13\%). On the other hand an insignificant proportion $(3.5 \%)$ of the rice farmer obtained credit facility from commercial banks. The high proportion of respondents who source credit from cooperative may be attributed to the fact that most of the respondents were members of an association. These therefore have enhanced their access to credit. The result is in line with the findings of Olasunkanmi et al., (2013), who reported that cooperative society is a veritable tool for capital formation and agricultural development. 
Table 3: Factors that determine access to credit by the smallholder rice farmers

\begin{tabular}{lll}
\hline Variable & Coefficient & Z-stat \\
\hline Constant & 0.1171 & 0.0512 \\
Education level & $(2.2890)$ & \\
Extension contact & 0.0535 & 0.6004 \\
& $(0.0891)$ & \\
Farm size & $-1.5515^{\star * *}$ & -2.9424 \\
Farming experience & $(0.5273)$ & \\
& $0.0443^{* * *}$ & 3.245 \\
Gender & $(0.0136)$ & \\
& $0.0826^{*}$ & 1.9041 \\
Household size & $(0.0434)$ & 0.3479 \\
& 0.2186 & \\
Marital status & $(0.6284)$ & 2.5079 \\
& $0.3232^{* *}$ & \\
& $(0.1289)$ & 0.7515 \\
\hline
\end{tabular}

***, ** and *, Significant at $P<0.01, P<0.05$, and $P<0.10$, respectively. log likelihood is -47.1046 ; MacFadden $\mathrm{R}^{2}$ is 0.2630 ; LR statistic $=18.3524$.

Table 4 shows the factors that determine the access to credit by the small holder farmers. The MacFadden R-square of 0.26 implies that all the explanatory variables included in the model were able to explain $26 \%$ of the variation in factors that determines the access to credit by the small holder rice farmers in the study area. Specifically, farm size $(0.0443)$ had a positive influence on credit access and was statistically significant at $1 \%$. This implies that an increase in area of land will increase the access to credit. Also, the variable household size $(0.3232)$ had a positive and significant influence on credit access at $5 \%$ level of significance. This implies that as the household size increases, it creates room for expansion and this will increase the need to access more credit. Farming experience $(0.0826)$ had a positive and significant influence on credit access by farmers at $10 \%$ level of significance. This implies that with more years spent in rice farming the greater the opportunity to have access to credit. The result agrees with that of Nouman et al., (2013), they reported that farm size and farming experience have a positive influence on access to credit by farmers. Extension contact $(-1.5515)$ had a negative and significant influence on the access to credit by the farmers at $1 \%$ level of significance. The negative influence could be as a result of the fewer visits by extension to the rice farmers. The result is at variance with that of Adeyonu et al., (2017) who carried a study on the factors that influence access to credit by poultry farmers in Abuja. They reported that extension visit has a positive influence on credit access. 
Table 4 Maximum Likelihood Estimates of the Parameters of the Stochastic Frontier Production Function

\begin{tabular}{lllll}
\hline Variables & Parameters & Coefficient & Std. error & t-ratio \\
\hline Production Factors & & & & \\
Constant & $\mathrm{b}_{0}$ & 4.816 & 0.996 & 4.835 \\
LnQuantity of seed (X1) & $\mathrm{b}_{1}$ & 0.3655 & 0.0941 & 3.886 \\
LnFarm size (X2) & $\mathrm{b}_{2}$ & 0.0684 & 0.0193 & 3.538 \\
Lnfertilizer (X3) & $\mathrm{b}_{3}$ & 0.0763 & 0.0668 & 1.14 \\
LnHired labour (X4) & $\mathrm{b}_{4}$ & -0.242 & 0.233 & -1.039 \\
LnFamily labour(X5) & $\mathrm{b}_{5}$ & 0.572 & 0.240 & 2.38 \\
& & & & \\
Inefficiency effects & & & & \\
Constant & $\delta_{0}$ & 6.99 & 5.457 & 1.28 \\
Age (Z1) & $\delta_{1}$ & 0.022 & 1.355 & 1.62 \\
Marital status (Z2) & $\delta_{2}$ & -0.131 & 0.753 & 1.74 \\
Educational level (Z3) & $\delta_{3}$ & -0.113 & 0.033 & -3.436 \\
Household size (Z4) & $\delta_{4}$ & -0.693 & 0.284 & -2.436 \\
Farming experience $(Z 5)$ & $\delta_{5}$ & -0.015 & 0.004 & -3.013 \\
Extension service $(Z 6)$ & $\delta_{6}$ & 0.0166 & 1.004 & 1.165 \\
Access to credit (Z7) & $\delta_{7}$ & -0.0738 & 0.0268 & -2.756 \\
Diagnostic statistics & & & & \\
Sigma squared & $\left(\delta^{2}\right)$ & 1.706 & 0.539 & 3.165 \\
Gamma & $(\gamma)$ & 0.951 & 0.0196 & 48.65 \\
LR test & & 33.998 & & \\
Likelihood function & $(\Lambda)$ & -65.184 & & \\
Sample size & $\mathrm{N}$ & 85 & & \\
& & &
\end{tabular}

${ }^{* * *}(P<0.01) * *(P<0.05) *(P<0.10)$.all explanatory variables were expressed in natural log form. A negative sign of the parameter in the inefficiency function implies that the associated variable has a positive effect on technical efficiency level while a positive sign indicates otherwise.

Table 4 shows the result of the influence of credit and other factors on technical efficiency of rice farmers. The maximum likelihood estimation (MLE) of the frontier function revealed that $\sigma^{2}$ and $y$ are significant at 1 percent level. The significant value of the sigma square $\left(\sigma^{2}\right)$ indicates a good fit and correctness of the specified distribution assumption of the composite error term and also shows the presence of inefficiency effects and random error in rice production in the study area. The variable, quantity of seed $\left(X_{1}\right)$, farm size $\left(X_{2}\right)$, and family labour (X5) had a significant effect on the output of rice. The positive coefficient of quantity of seed $\left(X_{1}\right)$, farm size $\left(X_{2}\right)$, family labour $\left(X_{5}\right)$ were in line with a priori expectation and this implies that rice output increases with increase in these variables. The coefficient of quantity of seed $(0.3655)$ and farm size $(0.0644)$ were positive and statistically significant at $1 \%$ respectively. This implies that, increases in the level of use of these inputs will significantly increased output of rice in the study area.
The result obtained is in line with that of Erhabor and Ahmadu (2013). They obtained a positive relationship between quantity of seed and farm size. The coefficient of farm size was estimated at 0.0684 and statistically significant at $1 \%$ level, implying that a $1 \%$ increase in the hectares of land put into rice production will bring about increase in output of rice by $0.684 \%$. This is attributed to the relative importance of land in crop production and corroborates the findings of Wakili (2012). The result agrees with that of Olasunkanmi et al., (2013). Similarly, the variable family labour $\left(X_{5}\right)$ also had a positive and significant effect on rice output. The coefficient of family labour $\left(\mathrm{X}_{5}\right)$ was 0.572 and was statistically significant at $5 \%$ level of significance. The result implies that an increase in family labour $\left(X_{5}\right)$ will increase rice output in the area. This agrees with the findings of Omondi and Shikuku (2013). They reported that labour has a positive influence on paddy rice productivity. 
Table 5: Elasticities and return to scale (RTS) analyzes of production functions

\begin{tabular}{ll}
\hline \multicolumn{1}{c}{ Variables } & Elasticities \\
\hline seed $(\mathrm{X} 1)$ & 0.3655 \\
Farm size $(\mathrm{X} 2)$ & 0.0684 \\
fertilizer $(\mathrm{X} 3)$ & 0.0763 \\
Hired labour $(\mathrm{X} 4)$ & -0.242 \\
Family labour(X5) & 0.572 \\
Credit (X6) & 0.0738 \\
Return to scale (RTS) & 0.914 \\
\hline
\end{tabular}

Source: Computed from field survey, 2018.

The return to scale (RTS) analysis which serves as a measure of total resource productivity is given in Table 5. The result indicates that rice production was in Stage II (RTS $=0.914)$ of the production surface where production increases at decreasing rate. Stage II is the stage of decreasing positive return to scale. This implies that all inputs were used within the rational stage of production surface. This result was in line with that of Wakili et al.,(2015). The estimate of their RTS was 0.9162 and 0.7967 for both rain fed and irrigated rice farmers respectively. Hence, it is advisable, according to Ogundari and Ojo (2007) that production units should maintain current levels of input utilization, as this will bring about maximum output from a given level of output, ceteris paribus.

Table 6: Distribution of farm technical efficiency scores

\begin{tabular}{lll}
\hline Technical efficiency scores & Frequency & Percentages \\
\hline$\leq 0.30$ & 9 & 10.6 \\
$0.31-0.40$ & 5 & 5.9 \\
$0.41-0.50$ & 7 & 8.2 \\
$0.51-0.60$ & 9 & 10.6 \\
$0.61-0.70$ & 11 & 12.9 \\
$0.71-0.80$ & 24 & 28.2 \\
$0.81-0.90$ & 18 & 21.2 \\
$>0.90$ & 2 & 2.4 \\
Sample size & 85 & \\
Mean efficiency & 0.64 & \\
Minimum efficiency & 0.09 & \\
Maximum efficiency & 0.92 & \\
\hline
\end{tabular}

Source: Computed from field survey, 2018.

\section{EFFICIENCY ANALYSIS FOR RICE PRODUCTION}

The result in Table 6 shows the distribution of farmers according to technical efficiency. The technical efficiency is less than 1.0 indicating that all the farmers were producing below the maximum efficiency frontier. A range of technical efficiencies is observed across the sampled rice farmers and the spread is large. The most efficient (maximum efficiency) had technical efficiency of 0.92 (or $92 \%$ ), while the least efficient farmer had a technical efficiency of 0.09 (or $0.9 \%$ ). The mean technical efficiency is 0.64 (or $64 \%$ ). This implies that, on the average, the farmers were $64 \%$ technically efficient; hence their observed output was about $36 \%$ (efficiency differential) less than the maximum frontier output. The large variation in technical efficiency estimates is an indication that most of the farmers were not using their resources efficiently. The mean technical efficiency of 0.64 from this research is in line with the 0.61 and 0.63 obtained respectively for rice production by Onyenweaku and Ohajianya (2005) in Ebonyi state.

The distribution of the efficiency analysis also revealed that $24.7 \%$ of the respondents had technical efficiency of about $50 \%, 51.7 \%$ had technical efficiency of $51-80 \%$ while $23.6 \%$ had technical efficiency of 81 and above. A study by Ebong (2009) on the efficiency of urban farming in Nigeria, they 
found that all farmers were producing below the maximum efficiency frontier. The farmer's technical index varied from $10 \%$ to $95 \%$, with a mean technical efficiency of $81 \%$.

\section{DETERMINANTS OF TECHNICAL EFFICIENCY OF SMALL SCALE RICE FARMERS}

The parameter estimates from the inefficiency model included in the stochastic production frontier estimation (Table 4), was used to determine the factors influencing farmers technical efficiency of the rice farmers in the study area. For technical inefficiency model, the coefficients of educational level, household size, farming experience and credit was negative and significantly related to technical inefficiency at different level of significance. This result implies that an increase in these variables will decrease the technical inefficiency but increase the technical efficiency.

Specifically, household size was negatively $(-0.693)$ related to technical inefficiencies. This implies that household size has a positive effect on technical efficiency and large family produce more labour force for rice production. This agrees with the findings of Onyenweaku and Nwaru, (2005) who noted that household size has an advantage on labour supply tremendously.

The coefficient of farming experience $(-0.015)$ was negative, implying that technical efficiency among farmers increases with more years of experience in farming and vice versa. The more experienced a farmer is the more efficient his ability to make decisions on his own (Onyenweaku and Okoye, 2007), therefore farmers experience helps a lot for efficiency in production. This corroborates the finding of Fassasi (2007) who reported that increase in farming experience reduces technical inefficiency.

Similarly, the estimate for educational level $(-0.113)$ was negative and significantly related to technical inefficiency at $1 \%$. This implies that an increase in these variables may increase the technical efficiency of the farmers. Ogunniyi et al. (2012) obtained a negative relationship between educational level and technical inefficiency in their study.

Furthermore, the inefficiency function shows that credit $(-0.0738)$ negatively influences inefficiency at $5 \%$ level of significance. This indicates that the volume of credit increases the technical efficiency of the rice farmers. Availability of credit to farmers at the right time, bearing in mind the timeliness of agricultural production could help increase the resource use efficiency in rice production. Bathon and Maurice (2015) also obtained a negative relationship between access to credit, educational level and technical inefficiency. Duy (2015) reported that credit has a positive influence on production and production efficiency. Also, Martey, et al., (2015) reported that credit impacted positively on farmers' technical efficiency. The study concluded that the provision of credit enhanced timely purchase and efficient allocation of factor inputs to produce the maximum output.

\section{CONCLUSION AND RECOMMENDATION}

i. Extension activities should be increased in the study area and they should focus on improve techniques of rice production and encourage farmers to use available resources efficiently and effectively.

ii. Financial institutions should be encouraged to collaborate with agricultural and farmer development projects to facilitate credit delivery to smallholder farmers.

iii. The smallholder rice farmer should increase access to credit per production season, since the access to credit has efficiency increasing effect.

iv. In order to improve efficiency in resource allocation in rice production, it is recommended that input such as farm size, labour, seed, etc should be made available by subsidizing the price by government and non-governmental organization so that farmers can increase the use of these input.

$v$. There is need for the government to formulate policies aimed at promoting education as a means of enhancing efficiency in rice production, as this will enable the farmers to use their resources efficiently.

\section{REFERENCES}

Akinnagbe, O. M. and Uchechukwu, A. A., 2014. Rural farmers sources and use of credit in Nsukka local government area of Enugu state, Nigeria. Asian Journal of Agricultural Research, 8(4), 195-203.

Akande, T.. 2002. An overview of the Nigerian Rice Economy, Monograph Series. Nigerian Institute of Social and Economic Research (NISER) Ibadan, 11pp.

Battesse, G. E. and Corra, G. S., 1977. Estimation of Production Frontier Model: with Application to the Pastoral Zones of Eastern Australia. Australian Journal of Agricultural Economics, 22, 167-179.

Brambilla, I. and Porto, G. G., 2005. Farm Productivity and Market Structure: Evidence From Cotton Reforms in Zambia, Access on 29/03/2018 at: http://www.depeco.econo.unlp.edu.ar/semi03 0605.pdf

Coelli, T. J., 1996b. Guide to FRONTIER Version 4.1: A Computer Program for Stochastic Frontier 
Production and Cost Function Estimation, CEPA Working Paper 96/7. Armidale NSW Australia., Department of Econometrics, University of New England.

Duy, V. Q., 2015. Access to Credit and Rice Production Efficiency of Rural Households in the Mekong Delta. Sociology and Anthropology, 3(9), 425-433.

Erhabor, P. and Ahmadu, J., 2013. Technical efficiency of small-scale rice farmers in Nigeria. Journal of Agriculture and Allied Sciences, 2(3), 14-21.

Food and Agricultural Organization (FAO) 2015. FAO production year Book, Rome.

Guirkinger, C. and Boucher, S., 2005. Credit constraints and productivity in Peruvian agriculture. Department of Agricultural and
Resource Economics, University of CaliforniaDavis.

Martey, E., Wiredu, A. N. and Etwire, P. M., 2015. Impact of credit on technical efficiency of maize producing households in Northern Ghana. Selected Paper presented at the Centre for the Study of African Economies (CSAE) Conference 2015, University of Oxford, March 22-24, 2015.

Oladeebo, J. O., 2007. Determinants of Loan Repayment among Smallholder Farmers in Ogbomoso Agricultural Zone of Oyo State, Nigeria, Journal Social Science 17,59-62.

West Africa Rice Development Association (WARDA) (2003). The Nigerian rice economy in a competitive world: Constraints, opportunities and strategic choices. Strategy for rice sector revitalization in Nigeria.

NOMREG VAR00001 (BASE=LAST ORDER=ASCENDING) BY VAR00002 VAR00003 VAR00004 WITH VAR00005 VAR00006 VAR00007 VAR00008 VAR00009 VAR00010 VAR00011 VAR00012 VAR00013 VAR00014 /CRITERIA CIN (95) DELTA (0) MXITER (100) MXSTEP(5) CHKSEP (20) LCONVERGE (0) PCONVERGE(0.000001) SINGULAR(0.00000001)

/MODEL/STEPWISE=PIN (.05) POUT (0.1) MINEFFECT (0) RULE (SINGLE) ENTRYMETHOD (LR) REMOVALMETHOD (LR) /INTERCEPT=INCLUDE /PRINT=PARAMETER SUMMARY LRT CPS STEP MFI.

\section{Nominal Regression}

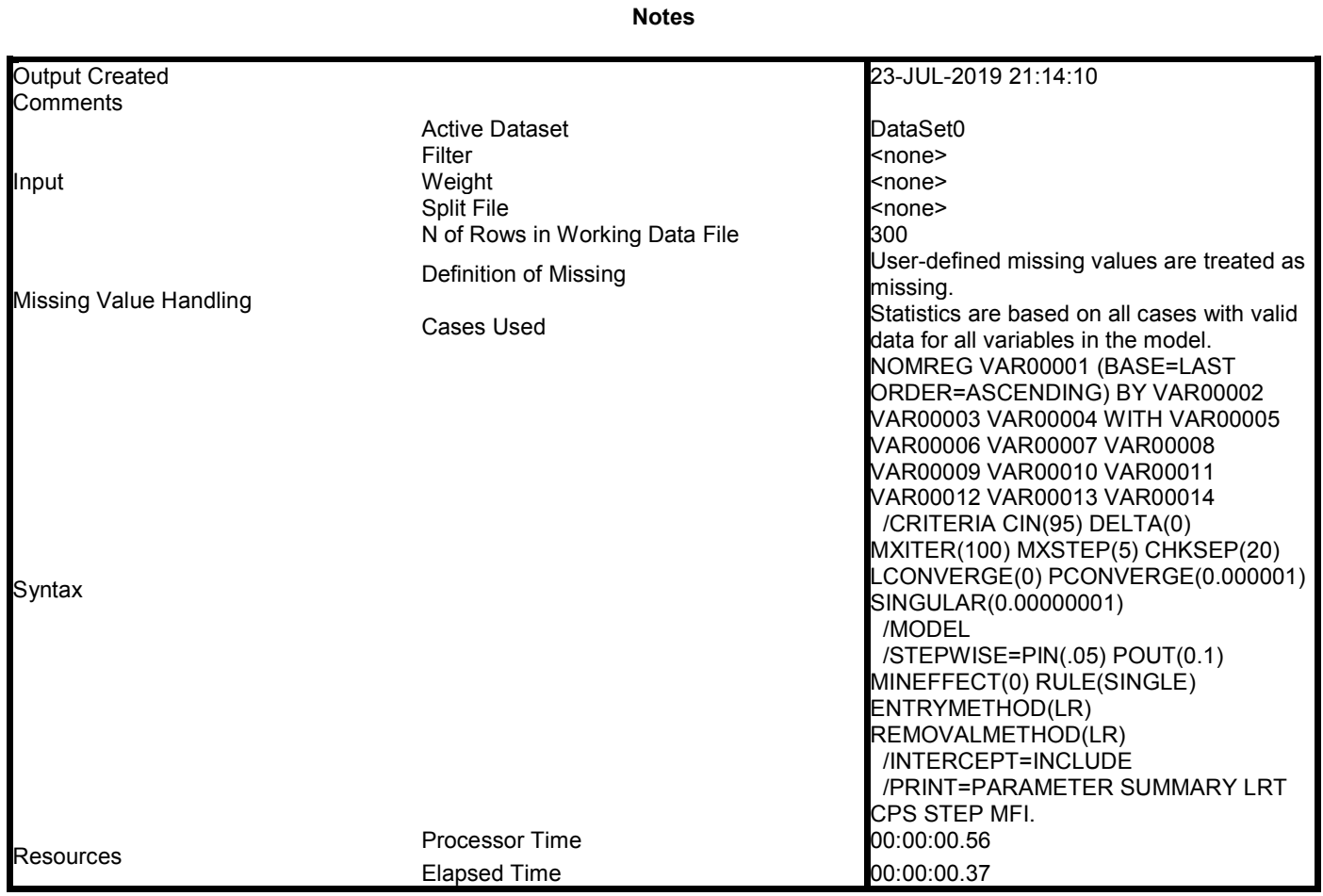

[DataSet0] 
EDET, O. G., AGBACHOM E. E. AND UWAH, E. D.

Case Processing Summary

\begin{tabular}{|ll|l|l|}
\hline & & $N$ & $\begin{array}{l}\text { Marginal } \\
\text { Percentage }\end{array}$ \\
\hline VAR00001 & .00 & 67 & $22.4 \%$ \\
& 4.00 & 232 & $77.6 \%$ \\
VAR00002 & .00 & 186 & $62.2 \%$ \\
& 3.00 & 113 & $37.8 \%$ \\
VAR00003 & .00 & 224 & $74.9 \%$ \\
& 2.00 & 75 & $25.1 \%$ \\
VAR00004 & .00 & 208 & $69.6 \%$ \\
Valid & 1.00 & 91 & $30.4 \%$ \\
Missing & & 299 & $100.0 \%$ \\
Total & & 1 & \\
Subpopulation & 300 & \\
\hline
\end{tabular}

a. The dependent variable has only one value observed in $299(100.0 \%)$ subpopulations.

Model Fitting Information

\begin{tabular}{|l|l|l|l|l|}
\hline \multirow{2}{*}{ Model } & Model Fitting Criteria & Likelihood Ratio Tests & \\
\cline { 2 - 5 } & -2 Log Likelihood & Chi-Square & df & Sig. \\
\hline Intercept Only & 318.150 & 102.298 & 13 & \\
Final & 215.853 & .000 \\
\hline
\end{tabular}

Pseudo R-Square

\begin{tabular}{|l|l|}
\hline Cox and Snell & .290 \\
Nagelkerke & .442 \\
McFadden & .322 \\
\hline
\end{tabular}

Likelihood Ratio Tests

\begin{tabular}{|l|l|l|l|l|}
\hline \multirow{2}{*}{ Effect } & Model Fitting Criteria & Likelihood Ratio Tests & \multicolumn{2}{l|}{} \\
\cline { 2 - 5 } & -2 Log Likelihood of & Chi-Square & df & Sig. \\
& Reduced Model & & 0 & \\
\hline Intercept & $215.853^{\text {a }}$ & .000 & 1 & .375 \\
VAR00005 & 216.641 & .789 & 1 & .001 \\
VAR00006 & 226.329 & 10.476 & 1 & .831 \\
VAR00007 & 215.898 & .046 & 1 & .034 \\
VAR00008 & 220.360 & 4.507 & 1 & .142 \\
VAR00009 & 218.009 & 2.157 & 1 & .845 \\
VAR00010 & 215.891 & .038 & 1 & .542 \\
VAR00011 & 216.224 & .371 & 1 & .368 \\
VAR00012 & 216.662 & .809 & 1 & .382 \\
VAR00013 & 216.617 & .765 & 1 & .854 \\
VAR00014 & 215.886 & .034 & 1 & .000 \\
VAR00002 & 229.764 & 13.911 & 1 & .000 \\
VAR00003 & 252.918 & 37.065 & 1 & .000 \\
VAR00004 & 235.042 & 19.190 & 1 & \\
\hline
\end{tabular}

The chi-square statistic is the difference in -2 log-likelihoods between the final model and a reduced model. The reduced model is formed by omitting an effect from the final model. The null hypothesis is that all parameters of that effect are 0 . a. This reduced model is equivalent to the final model because omitting the effect does not increase the degrees of freedom. 


\section{Parameter Estimates}

\begin{tabular}{|c|c|c|c|c|c|c|c|c|c|}
\hline \multirow{2}{*}{\multicolumn{2}{|c|}{ VAR00001 ${ }^{\mathrm{a}}$}} & \multirow[t]{2}{*}{$B$} & \multirow[t]{2}{*}{ Std. Error } & \multirow[t]{2}{*}{ Wald } & \multirow[t]{2}{*}{ df } & \multirow[t]{2}{*}{ Sig. } & \multirow[t]{2}{*}{$\operatorname{Exp}(B)$} & \multicolumn{2}{|c|}{$\begin{array}{l}95 \% \text { Confidence Interval } \\
\text { for } \operatorname{Exp}(B)\end{array}$} \\
\hline & & & & & & & & $\begin{array}{l}\text { Lower } \\
\text { Bound }\end{array}$ & Upper Bound \\
\hline \multirow{17}{*}{.00} & Intercept & 5.128 & 1.497 & 11.732 & 1 & .001 & & & \\
\hline & VAR00005 & -.077 & .087 & .786 & 1 & .375 & .926 & .781 & 1.098 \\
\hline & VAR00006 & -.322 & 102 & 10.003 & 1 & .002 & .725 & .593 & .885 \\
\hline & VAR00007 & -.047 & 222 & .046 & 1 & .831 & .954 & .617 & 1.473 \\
\hline & VAR00008 & -.337 & .164 & 4.260 & 1 & .039 & .714 & .518 & .983 \\
\hline & VAR00009 & -.216 & 148 & 2.122 & 1 & .145 & .806 & .603 & 1.077 \\
\hline & VAR00010 & .023 & 120 & .038 & 1 & .845 & 1.024 & .810 & 1.294 \\
\hline & VAR00011 & .164 & 270 & 371 & 1 & .543 & 1.179 & .694 & 2.000 \\
\hline & VAR00012 & .000 & .000 & .845 & 1 & .358 & 1.000 & 1.000 & 1.000 \\
\hline & VAR00013 & .023 & .026 & .753 & 1 & .386 & 1.023 & .972 & 1.077 \\
\hline & VAR00014 & .088 & .480 & .034 & 1 & .855 & 1.092 & .426 & 2.799 \\
\hline & [VAR00002=.00] & -1.310 & 361 & 13.141 & 1 & .000 & 270 & .133 & .548 \\
\hline & [VAR00002=3.00] & $0^{b}$ & & & 0 & & & & \\
\hline & [VAR00003=.00] & -2.208 & 385 & 32.801 & 1 & .000 & 110 & .052 & .234 \\
\hline & [VAR00003=2.00] & $0^{b}$ & & & 0 & & & & \\
\hline & [VAR00004=.00] & $\begin{array}{l}-1.571 \\
0\end{array}$ & 371 & 17.925 & 1 & .000 & 208 & .100 & .430 \\
\hline & [VAR00004=1.00] & $0^{\mathrm{b}}$ & & & 0 & & & & \\
\hline
\end{tabular}

a. The reference category is: 4.00 .

b. This parameter is set to zero because it is redundant. 